\title{
INTERTEXTUAL PARAMETERS OF THE DRAMATIC PERSONALITY OF SOPHOCLES' PHILOCTETES AT ANDRE GIDE AND YANNIS RITSOS
}

\author{
UDC 821.133.1.09 Žid A. \\ 821.14'06.09 Ricos $J$.
}

\section{Panagiotis Asimopoulos}

Hellenic Army Academy, Kitsi, Greece

\begin{abstract}
Undoubtedly the constructive, dialectical relation of the literary works reflects the significant and diachronic people's need to be orientated towards revived cells of the archetypal core, but also to the actualized motives related to their mythic foundation. This universal ascertainment is verified by the fact that famous and gifted creators adopt the unparalleled spirituality and the profound messages that spontaneously spring from selected verses of classic Greek tragedies. In a perfect connection with intellectually enlightened Sophocle Andre Gide, perspicacious Proteus of the French dramaturgy and Yannis Ritsos, the revolotionary figure of the Modern Greek poetry deal with Philoctetes, the legendary archer: Thus the puritanical nuance of bourgeois arrogance and the unrestrained, youthful impulsiveness are bridged at Gide's "Philoctetes" (1898). At the same time the anticonventional, hedonistic poet's gens are harmonized ideally with the standards of the traditional literature. Analogously at the homonymous poem of the awarded collection "The Fourth Dimension" (1963-1965), at this non-marxist inspiration Yannis Ritsos released from political beliefs approaches the existentialistic balance of the conscious choice between the active, social responsibility and the subjugated art.
\end{abstract}

Key words: Philoctetes, Sophocles, Gide, Ritsos

\section{INTRODUCTORY NOTES}

At an intercultural level, the strong interaction between competing ${ }^{1}$ ancient Greek myths and literary inspirations of contemporary creators is based on the constructive

\footnotetext{
Submitted September $7^{\text {th }} 2017$, accepted for publication December $13^{\text {th }}, 2017$

Corresponding author: Panagiotis Asimopoulos

Hellenic Military Academy, Kitsi, Greece

E-mail: asimopoulosp@yahoo.gr

${ }^{1}$ Griffith (1990: 188) notes: "All societies contain some measure of this impulse towards individual selfassertion and competition; but among the Greeks from the earliest times it seems to have been exceptionally strong. In this contest-system, the arts (mousikê), and poetry in particular, comprised a very popular and prestigious arena of competition, and it is hardly an exaggeration to say that most Greek poetry, from the time
} 
dialogue of semantic relationships and integrated utterances that reflect how their intellectual exponents perceive the world (Todorov 1981: 96).

Having tragic Philoctetes as its thematic motif and within the diachronic mytheme (Levi-Strauss 1974: 234) of the Sophoclean inspiration (409 B. C.), without the methodologically incorrect identification with Alcibiades ${ }^{2}$ of the Peloponnesian War, the artistic conjugation of the literary $\mathrm{myth}^{3}$ of André Gide and Yannis Ritsos is manifested.

\section{THE LITERARY RECEPTION OF MythiCAL PHILOCTETES}

Philoctetes was the skilful $\operatorname{archer}^{4}$ who the demigod Hercules ${ }^{5}$ has bequeathed his bow ${ }^{6}$ and poisoned arrows, since he contributed to the touch of his funeral pyre. He took part in the famous Argonautic expedition'. In Homer, he is presented as one of Helen's ${ }^{8}$ suitors and head of seven ships and fifty men ${ }^{9}$ who were rowers and warriors ${ }^{10}$ as well. However during a sacrifice at the altar of Nymphe Chrysis ${ }^{11}$, which was on the homonymous island (Webster 1985: 28) near Lemnos, Hephaestus' island ${ }^{12}$ a poisonous viper bit his leg. Due to the caused contamination, the unstoppable bleeding, the unbearable pains and in general the disgusting situation ${ }^{13}$, the Achaeans leave him helpless (Lesky 1987: 399), although he is said to have been taken care of Iphimachus,

of Homer and Hesiod to that of Euripides, was composed for performance in an explicitly or implicitly agonistic context. In this respect, it is fundamentally different from most Roman, and most later European, poetry".

2 According to Jameson (1956: 219): "The interpretation is not to be dismissed out of hand but should be considered in the light both of the historical situation and of the particular plot the poet has contrived; and here it fails. The poet is not telling his countrymen they need a Philoctetes; the need for Philoctetes is a fact taken from the traditional story and never really questioned. He is more concerned with Philoctetes' reaction to the need of the Greeks. The hero is unmoved by human appeals; only a god can make him return to war. Contrast with this the actual position of Alcibiades: by the time of the play's production in the spring of 409 B.C. he had been for almost two years the powerful commander of a victorious Athenian fleet (whatever the anomalies of his official position), after opening negotiations himself for his return; he was a most enthusiastic proponent of continuing the war at all costs (as he had informed the 400); and. finally, a decree had been passed in the winter of $411 / 10$ B.C. recalling him. None of this suits the miserable Philoctetes who can only be brought to join the war by a theophany. There is also a clear disparity between the public character of Alcibiades (whatever the poet himself may have thought of him) and Philoctetes. Indeed, if we accept the popular picture of Alcibiades he has more in common with Odysseus: the subordination of all else to victory (cf. 11. 81, 1052), the clever mind and false tongue so apparent in the Samian dealings (cf. 11.96-99, 109, 119), and what Plutarch calls his most distinctive quality, his chameleon-like adaptability, his chief instrument in the hunting of men".

3 Albouy (1969: 9) comments: "The literary myth is essentially a narrative that has added new meanings to the historical myth".

${ }^{4}$ Hom., Od., 8. 219-220

${ }^{5}$ Avery (1965: 291) points out: "Quite to the contrary, it seems very likely that Sophocles was the first to change Philoctetes' homeland and set him in country closely identified with Heracles. This could be done more easily because Philoctetes was a relatively minor figure in the epic tradition".

${ }^{6}$ Taplin $\left(2003^{2}: 89\right)$ stresses: "[...] the most integrally incorporated of all material objects in the Greek tragedy we have"

${ }^{7}$ Hyg., Fab., XIV

${ }^{8}$ Apd., Bibl., III, 10, 8

${ }^{9}$ Hom. Il., 2.718-723; Apd., Ep., 3, 14; Hyg., Fab., XCVII

${ }^{10}$ Thuc. 1.10 .4

${ }^{11}$ Paus. 8.33.4

${ }^{12}$ Eisner (1987: 239) displays the similarities between Philoctetes and Hephaestus

${ }^{13}$ Korsmeyer (2011: 15) claims that the feeling of disgust is distinguished in "one that stresses the connection of emotional responses to belief systems and cultures, and one that focuses on their physical, reactive character" 
the shepherd of king Actor ${ }^{14}$. After the ten-year Trojan War the hero returned safely to his homeland ${ }^{15}$ or he perhaps navigated to Campania, Italy ${ }^{16}$.

A brief reference to Filoctetes, without quoting essential information, is made in Pindar's Pythian ${ }^{17}$, but also in the summary of the lost epic "Little Iliad" of Lesches, as it is preserved by grammarian Proclus (Westphal 1866: 238-239). It is know that Sophocles had composed the drama "Philoctetes in Troy" (Pearson 1917: 309-313). In addition, Aeschylus and Euripides ${ }^{18}$ were inspired by Philoctetes' adventures.

In the modern era, established European dramaturgists (Roisman 2005: 112-125) dealt thoroughly with his legendary life (Jebb $1898^{2}$ : xxxiii-xxxv): the French Roman Catholic archbishop François Fénelon in the didactic novel "Les aventures de Télémaque, fils d' Ulysses" (1762); the member of French Academy Jean-Baptiste Châteaubrun in his tragedy "Philoctète" (1756); the English Romantic poet William Wordsworth in his sonnet "When Philoctetes in the Lemnian Isle" (1888); the East German postmodern dramatist Heiner Müller with a successful adaptation in "Philoktet" (1968); Adrienne Rich in Poem VIII of "Twenty One Love Poems" (1976); Michael Ondaatje in two poems: "The Goodnight" and "Philoctetes on the Island" that appear in the book "There's a trick with a knife I'm learning to do" (1979); the literary critic Laurence Lerner in his collection "The Man I Killed" (1980); the French winner of the Nobel Prize in Literature (1947) André Gide in the play "Philoctète"(1981) and also the Northern Irish Nobelist (1995) poet Seamus Heaney in "The Cure at Troy. A Version of Sophocles' Philoctetes" (1991).

The steadfast adhesion to the Sophoclean hero reflects the uninterrupted resonance highlighted by the complicated topics of essential communication and inevitable alienation (Easterling 1978: 27-39). The role of his dramatic physiognomy allowing multidimensional interpretations that are smoothly incorporated into the psychospiritual framework and the dynastic concerns of contemporary readers seems to be catalytic.

\section{ANDRÉ Gide AND the GreEK Mythical Heritage}

The French playwright as an outstanding expert of Greek mythology and classical literature masterfully portrays versatile and unpredictable Proteus. By defending the "place where two literary perceptions meet each other: the traditional art, which puts above everything the happiness to produce masterpieces and the literature as an experience that is indifferent to the works, but is ready to self destruct in order to approach the inaccessible" (Blanchot 1989: 63). Gide levitates at the fragile boundaries between the imposed moral law, the strict Christian doctrines and the insurmountable attraction stemming from the impulsive dynamics of hedonistic anti-reformism and youthful creativity. Thus "the prince of doubt or even the demon himself" (Blanchot 1989: 64), is surrendered to the relentless tug-of-war of mature moderation and courageous extrovertness; he reminds "a child who has fun, since his company is a Protestant pastor who extremely bothers him" (Fernandez 1989: 27). The acrimonious result of Gide's unparalleled writing through which "he wants to establish a compromise between the danger and the rule;

\footnotetext{
${ }^{14}$ Hyg., Fab., CII

${ }^{15}$ Hom., Il., 2. 724-725; Hom., Od., 3.190

16 Apd., Ep., 6, 15

${ }^{17}$ Pind., P., 1. 50-55

${ }^{18}$ Dio Chrysostom, Orat., 52.2
} 
within him the Protestant law and the homosexual anti-conformism are balanced, as well as the presumptuous individualism of the bourgeois and the puritanical attitude of social pressure" (O'Brien 1953: 5) is that he subjects us to a conscious review of all elements which "now will be said - this is his boldness - but according to some rules of elegance that is his pledge" (Sartre 1989: 32).

Using as concentric circles the established myths that "are given material we can always return to, bend over, study its symbols, recreate, contemplate, make art" (O' Brien 1953: 9), enlightened Gide deals with the multifaceted physical renewal. He pursues the spiritual resurrection, while at the same time he praises the strategic contribution of multidimensional education of the individual to his correct orientation towards the regaining of his lost totality.

In the myths the experiential truths that aim at individual freedom and ground the universal evolution are perpetually recycled. Furthermore they reinforce the inner destiny that expels the archaistic supernatural destiny, as the domination of divine grace is tenuous, because it is weakened and almost deposed; they proclaim the titanic effort of immortals and human beings to preserve their non-negotiable authenticity; they accelerate the selfknowledge course, because "going ahead is the command that leads the hero to adventures, feats, dangers, and love" (Gide 1948: 356).

Thus Gide's poetic art involves objective of self-comfort. By imitating Ovid's and Pushkin's works of exile Gidean Philoctetes is identified as "an innovation in the sense that a new way of poetic self-interpretation introduced in the European literature is ascertained: the idea of a poem addressed only to the poet" (Stroh 1981: 2645). His complete dissociation from the diseased social environment (Blanchot 1989: 62) is perceived as the appropriate antidote for the widespread analgesia; as a coherent bond he bridges the wounded creature's substance with the final stage of his self-completion.

\subsection{Sophoclean vs. Gidean "Philoctetes"}

The Sophoclean drama, although functioning as the main thematic core of Gide's tragedy "Philochetes", is approached with remarkable originality, as it is evidenced by the alternative title "Le traité des trois morales". However in terms of its morphological structure, Gide's inspiration is characterized by remarkable differences:

(a) At Gide's play the deserted place (Feder 1963: 33) of Lemnos, where Philoctetes has been abandoned is converted into a frozen island, in a polar landscape surrounded by icebergs, where someone can arrive after a fatiguing journey of fourteen days. The dominant infertility that is clearly apparent serves the writer's directorial perspective: Philoctetes' nihilistic thinking, his psychic disfigurement fits in the island that is "...the expression of almost complete intellectual abstraction" (Watson-Williams 1967: 59). The prevailing isolation (Alpers 2004: 4-19) attracts and repels the troubled hermit. On account of this, after Odysseus' and Neoptolemus' brief visit, he feels gladness and considers that his unexpected happiness reflects on the brilliant image.

(b) Inventive Odysseus accompanied by inexperienced Neoptolemus ${ }^{19}$ asks Philoctetes for his legendary bow. In Sophocles, Odysseus insists to the young man that the necessary

\footnotetext{
${ }^{19}$ Jameson (1956: 224) equates Neoptolemus with Pericles the Younger, the son of the famous statesman and Aspasia: "how much or how little this parallel may mean is certainly debatable. For none of the three characters
} 
precondition for the achievement of their plan is to gain fraudulently the trust of the resentful herb. Only if they pretend to be bitter enemies of Achaeans, they will provoke his avenging anger, and they will mislead him skilfully. He doesn't present any logical arguments in order to justify his thoughts that are evident in the French play: Odysseus invokes the "ethics of social order" (Albouy 1969: 271; Claude 1992: 52). The fair or unfair fulfilment of the bounden duty towards homeland in any way constitutes a supreme indication of virtue and submission. Additionally, the high motivation of official recognition inspires Sophoclean Neoptolemus.

(c) Hercules' immortal gift, that is the infallible bow with the poisonous arrows has little value at Gide's drama: for Philoctetes their unprompted offer constitutes the high price he generously pays for the long-awaited acquisition of supreme peace; it is the ideal means of self-determined integration.

(d) In the Greek tragedy Neoptolemus reshapes his moral values (Hansaker 1999: 357 ) and manifests an extraordinary dynamism that reaches the boundaries of the idle behaviour, as he is strongly opposed to wise Odysseus (verses 1230-1250). Ten years after the fall of Troy, he is resolved on returning the bow to his owner. At Gide the young man is about to die. He behaves with exemplary respect and shocking innocence, elements that recall harmless Isaac, the son of devout Abraham (Watson - Williams 1967: 63).

(e) In the ancient melodrama (Craik 1979: 15-29) as directly the hero who feels cursed and thirsty for his immediate recovery to social events as indirectly his valuable bow act as a necessary element for the conquest of Troy (verses 610613). But at Gide Philoctetes has been compromised on absolute loneliness and he remains spineless on the island, since his active participation in the expedition is not of prime importance.

(f) The gluttonous plague (v. 313) on Philoctetes' rotten foot causes unbearable pains, so that Chorus himself confesses: "He has told of a struggle with sufferings manifold and oppressive - may the like befall no friend of mine!" (verses 507-509). But also the disgusting smell ${ }^{20}$ (versus 1032) has a significant effect on his external appearance and mental serenity, as it converts it into "one so wretched and so lonely, a castaway, so friendless and so miserable" (verses 227-228). On the contrary at Gide Philoctetes treats positively the malodorous foot, though it takes him away from his fellow humans. In such objectively unbearable and non-ideal conditions of untold physical discomfort, mental suffering and ascetic patience the virtue flourishes. There the curse of passive isolation turns into an active blessing. ${ }^{21}$

(g) The surprising appearance of the warriors who wear traditional Greek clothes and use the "cherished sound" (versus 234) bring back to the memory of the isolated Sophoclean hero his dramatic appeals to the sailors for repatriating him (verses 307-311), reflects his indomitable desire for human contact. Instead Gide's

in this play is a one to one relationship with a contemporary figure or even type required, but for all three roles it would seem that the contemporary implication can be recognized".

${ }^{20}$ Kott (1976: 159-160) argues that " Philoctetes' fetid wound is simultaneously a holy wound. In the eyes of men became leper owing to the fact that he was chosen by the gods [...]. In Philoctetes this unceasingly running sore is the existential stigma of those who refused to agree with the gods, the history and the absurdity of the world".

${ }^{21}$ Louria (1952: 350) assumes that "the French writer insinuates Oscar Wilde's diversity that was even his [...].

Wilde whom Gide knew personally since 1891got out of prison in 1897 and was ostracized due to his 'wound' like Philoctetes". 
Philoctetes flooded by resentment because of the inhuman attitude of his comrades finds refuge in the redemptive self-isolation.

(h) "Deus ex machine" (Pucci 1994: 34) who in the tragedy with remarkable authoritarianism forces the lame hero to surrender the bow is invalidated by Gide: Philoctetes voluntarily drinks the hypnotic in order to enable the Greeks to steal his bow, because he realizes that the true virtue is at great risk near people.

(i) The alienated nature of the recluse reinforced by the torturing crises of his illness is an important factor that prompts the psychological transition of Neoptolemus and therefore causes his sincere mercy (verses 740-780). At Gide the young man adopts a milder stance because of the real love to a person who replaces the patriotism (Mandel 1981: 160) and his constant dedication to his tutor Philoctetes (verses 44-45).

(j) Chorus, whose role is always leading in every tragedy, as well as the merchant who reveals the oracle (verses 539-658) are absent from the modern drama where Odysseus at the beginning (verse 23) announces it to Neoptolemus.

\subsection{The principal dramatic persons}

Through a detailed approach to three persons Gide manages to describe the moral identity of virtue, as well as its actual incarnation:

Odysseus, Laertes' intelligent son follows his unique instinct and exploits his leading qualities. He resolutely pursues the success of the organized whole by adopting rigorous practices (Blundell 1987: 307-329). Like a genuine utilitarian opportunist (Tessitore 2003: 67) he ruthlessly deceives naive Neoptolemus by submitting to him misleading questions or he disrespects the speech and the beauty, since they have no practical consequences.

The prevailing conditions or the extraneous factors often instigate the individuals to follow the altruistic virtue. Although Odysseus is unable to capture the true parameters of authentic morality and Philoctetes' shocking self-denial, he spontaneously expresses real admiration as the brave archer voluntarily surrendered his bow for the sake of prosperity of his homeland.

Dignified Neoptolemus is reasonably disturbed because, as a young man, does not want to offer voluntarily his youth as a scapegoat to the ideals of homeland and gods. At the same time, a non-heroic death is in harmonized neither with his fervent soul nor with the famous sacred oath of Athenian teenagers ${ }^{22}$.

$\mathrm{He}$ is very young, so his sensitive soul has not yet been harmed by the pathogenic vanity of his corrupted elders. Although he is reasonably against the true purpose of the journey, he stubbornly refuses to behave with unmanly cowardice. He gradually differentiates his attitude $^{23}$ and assents, as he experiences the dynamic brainwashing through Odysseus' moralizing arguments (Podlecki 1966: 238) on patriotic sentiment.

Philoctetes' heartbreaking lament sensitizes Neoptolemus who reveals him their insidious plan: they will drug him and grab the precious bow ${ }^{24}$. Indirectly he seeks the

\footnotetext{
${ }^{22}$ Lyc. 1.77

${ }^{23}$ Calder (1971: 154) mentions: "I believe that the play has been fundamentally misunderstood because the character of Neoptolemus has been fundamentally misunderstood. He, I shall argue, rather than Odysseus is the archdeceiver".

${ }^{24}$ According to Lada-Richards (1997: 180) “[...] for large sections of the play's first audience, i.e. those who were memyêmenoi in the Eleusinian initiation rites, both the dramatic framing of Neoptolemus' plea (Phil. 654-675) as well as the emotions registered in its verbal level would have suggested a whole string of ritual associations falling into the realm of Eleusinian mystic initiation".
} 
exemption from his moral responsibilities, while he wonders if his courageous assumption is a clear indication of virtue. Then humble Philoctetes imitates Socrates of the Platonic dialogue "Meno", where the wise teacher with his obstetric method pretends to be ignorant of the question asked ("if virtue can be taught") ${ }^{25}$. With his live example he shows the right way.

Philoctetes, as a solitary eremite of the Old Testament, is in a very difficult position. He is abandoned in a frozen place, away from his beloved homeland. Emotionally empty and apparently disappointed at his comrades' treacherous behaviour (when he was no longer useful, they got rid of him in the most humiliating way) he understands that he must rely only on his physical strength and moral power. Only if he will be extricated from the baneful hatred and the revengeful fury against his fellow humans he will be humanized.

Fate has in store a cruel temptation for him: in spite of merciless struggle the achievement of inner peace is shaken, since the unworthy Greeks, the self-interested traitors ${ }^{26}$ who he has eradicated from his soul with severe pain want his insurmountable arc, as according to an oracle Troy would be seized only with Philoctetes' weapons. He wavers between established calmness and the highest calling of virtue; he resents due to the subtle diplomacy of incurable Odysseus while he is fascinated because of the unprecedented purity of emotional Neoptolemus; he fiercely conflicts against various manifestations of his "ego".

But the genuine thirst of visionary Neoptolemus to taste the unrivalled fruits of virtue functions as the real springboard for the individualized path to purification: although Philoctetes consciously drinks Neoptolemus' hypnotic in order to relieve them from possible remorses, once more they mistreat him shamelessly. In this way he becomes the leading figure who obtains "vertu individualiste et gratuite, pour qui le sacrifice et l'abnégation ne sont que des moyens de devenir une sorte de 'surhomme" (Csürös 1975: 356). Since his lively desire to impart humanistic ideals to Neoptolemus is hampered by heterogeneous interpretation, the happy hero prefers the perfect denial.

\section{YANNIS RITSOS" "PHILOCTETES"}

Yannis Ritsos wrote "Philoctetes" in May 1963 - October 1965, between two exiles in Athens and Samos (Maronitis 2006: 16). Based on the division of his work by Veloudis (1977: 17-20) into five development phases, this poem belongs to the last period of the fourth phase (1956-1966) or the "familiarity with fate" (Kouloufakos 1975: 26-27). During this period, in the political and social arena, the influence of the Greek Left rises and Ritsos was more involved in active politics. His substantial participation in political affairs and more specifically in the Communist Party provides special stimuli (Prokopaki 1981: 318-319). Meraklis (1981: 537) presents a vertically opposite opinion: Philoctetes is the most apolitical and non-Marxist work of the "Fourth Dimension", considering that the happened events take place in accordance with psychological factors rather than parameters of historical materialism. The dominant issue (Jeffreys 1994: 81) is directly related to every individual's imperative need to acquire not only political consciousness, even against his personal interests (verses 511-512), but also a conscious role in the unimpeded attainment of a common obligation (verses 533-534). Undoubtedly, the poet

\footnotetext{
${ }^{25} \mathrm{Pl} .$, Men,.70a

${ }^{26}$ Apd., Ep., 5.8
} 
exteriorizes his existential concerns about the militant action and the complete detachment or the social role of responsibility.

"Philoctetes" has been built on three levels (Prokopaki 1980: 5-6): the historicalmythological level within the accomplished combining is done by the consciousassociative parallelism of the mythical decade of the Trojan War with the critical historical decades of 1936-1946 and 1946-1956, where the tragic experiences of the generation of resistance and civilian war and those of the first post-war generation ${ }^{27}$ are met. In the common features of those decades and Ritsos' "Philoctetes" we should notice: deaths, war, mistakes, betrayals and also a new commitment for fulfilling the old debt. Also, there is evident the level of personal memory, namely the period of the poet's childhood, as it is reflected on Neoptolemus' words: the young man describing the paternal palace refers to the poet's home in Monemvasia. With exceptional eloquence the young man outlines his relatives paying special attention to his mother's psychological reconstitution. A correspondingly dominant role in Ritsos' mentality was played by his mother who was an educated and discreet woman with sophisticated taste (verses 141-143). Additionally Achilles' predominant form (verse 113) reminds perfectly the image of poet's father. In this case we find the memory of youth through Neoptolemus' similar experiences (verses 310-313). The tremendous dangers and the unbelievable discomforts of soldiers have parallels with Ritsos' personal adventures in the 1940s - 1950s. At the level of contemporary social problems and especially the rabid disputes of party leaders the verses 395-397 are related to the bloody clashes between resistance groups during the Second World War. A slight hue of such disharmony within the left movement or "of the existent and as they say the non-existent socialism" (Prokopaki 1981: 5) appears in the verses 376-377.

In conclusion, Bien's (1980: 70) insightful comment: "Ritsos chose a subject appropriate to his personal needs, which at the same time allowed him to express some deeper (even unspecified) truths about the national life of Greece and life in general" is verified.

\subsection{Philoctetes' structural characteristics}

The poem "Philoctetes" is written as a dramatic monologue where the main person is Neoptolemus. Paradoxically the recipient is Philoctetes who even though he is a mute interlocutor, displays so vividly his behaviour, fuzzy thoughts, that in essence a real dialogue takes place. In fact, the monologue acts as Neoptolemus' response to many years isolated hero.

In the myth Philoctetes suffers because of the terrible and fetid wound, as well as the treacherous behaviour of his comrades. In Ritsos the principal physiognomy is identified with a virile warrior or a mature man governed by excellent spirituality. There is a clear hint of the snakebite (verses 58-59) without mentioning the painful effects. It is impressive that Philoctetes himself from egotistical motives and humble incentives has caused it (verses 436-437) in order to withdraw (verses 56-58), but also to regain his inner peace through voluntary isolation (verses 63-64) and distance estimation of human errors (verse 60). The untold bitterness that overtires him is due to his unconsidered rejection by the Greeks (verses 423-425).

\footnotetext{
${ }^{27}$ Prokopaki (1981: 5) contends that the social conflicts of the 140s and 50s are reflected on the ten-year Trojan War; Bien (1980: 68, 71) believes that reference is made to the decade 1912-1922 that is full of wars and ends with a terrible disaster, but also to the decade 1940-1950 that splits the Greeks with relentless hatred.
} 
Taking advantage of painful experiences from the bloodthirsty war, the unhealthy wounds on the body and the unalterable scars in the soul Philoctetes realizes the impossibility of selfcentered ambition and ill-fated pursuits that is reminiscent of Neoptolemus (verses 396-398). He disagrees with the unjustified violence that apart from the universally acknowledged failure it irreparably poisons the human souls (verses 397-400). Disgusted with the political plots, the immoral betrayals and the cowardly meanness, he stands for troubled Neoptolemus (verses 377-379). He is aware that the silver-plated conversion of the once pure consciousness implies the shameless counterfeit of high visions (verses 379-381) and the immodest resignation from rightful goals (verses 376-377). Moreover Philoctetes is stripped of the warfare and impersonates the solitary ascetic, the withdrawn philosopher (verses 451-452), as he wishes to preserve the human dignity "by exchanging loquacious speech with stochastic silence" (Maronitis 2006: 22).

Now the great weapon in his quiver is the silence that acts as a bridgehead connecting the active existence with the unresponsive non-existence (verses 453-455) and as the intermediate phase between absence and presence (verses 456-458). He has acquired transparent dimensions similar to those governing Neoptolemus' mother (verses 212213). Thus, the painful feeling of unbearable, but fertile loneliness of the deliberately decommissioned hero is widespread (verses 458-459).

In his absolute isolation, he is untangled from old-fashioned perceptions of the past, released from his erroneous actions that were subjected to militaristic patterns and longs for spiritual freedom (verses 475-478). However, he courageously accepts the restrictive character and the threatening connotation of liberty (verses 500-501), which "makes anyone who bears it invulnerable and immortal, but at the same time, negatively, it isolates him from the dependencies of life" (Bien 1980: 139).

In his anguished inner battle the hero rests on deep reflection in order to be gradually led to the wise reaction and the mature evaluation of real circumstances. He is in a dilemma: to choose his immediate return to the irrational war in order to justify his dead fellow-fighters (verses 519-523) and satisfy Neptotlemus' heart-breaking request (verses 533-534) or to keep dying (verses 508-510) as a person enslaved to his lonely daily routine, where he surely feels solidarity for the countless dead ${ }^{28}$ who have been unjustly sacrificed on the greedy war altar (verses 524-527)

\section{2. "Philoctetes" at Sophocles and Ritsos}

The heavy fate of a sore and bitterly frustrated man who seeks trust (Lesky 1987: 410) is the thematic axis for Sophoclean "Philoctetes". Philoctetes' ten-year abandonment in Lemnos left bad mark on his mental state and stigmatized his external appearance that scares Neoptolemus. An additional negative contribution to the form of fury ${ }^{29}$ has been the "gluttonous plague" (verse 313) that struck his wounded leg, but also its terrible smell of "crippled and foul-smelling" (verse 1032). His difficult living conditions, the lack of real housing and the meagre diet played a negative role.

\footnotetext{
${ }^{28}$ Jeffreys (1994: 82) notes that since Metaxas' dictatorship the Communists were exiled to small Greek islands. Ritsos' first concentration camp was in Kontopouli of Lemnos (1948-1949).

${ }^{29}$ Lemnos, with all its loneliness and anxiety, did not turn him from a hero to a beast, but it grew the heroic discomfort for his trauma, made his intransigence absolute and increased his hatred for the enemies. These feelings dominate in the whole poem (Winnigton-Ingram 1999: 407)
} 
Philoctetes' absolutely justified wrath against the Greeks is sharpened towards the main responsible of his miserable life. For the aforementioned he gives terrible curses to both Atreids (Agamemnon - Menelaus) and Odysseus. His abyssal odium is shown when Neoptolemus visits him in his hermitage, so that he return to the battlefield and the Achaeans might win the war. Until Hercules' appearance as "deus ex machine" ${ }^{30}$ the ensured great reputation, the offered remedy as well as the true prospect of salvation couldn't manage to diminish his deeply rooted hostility.

At Yannis Ritsos' poem we may find characteristic divergences:

(a) Feisty Philoctetes aims at his conscious decision and forceful withdrawal on the desert island, as he considers that this is a unique opportunity for substantial navel-gazing and constructive regaining of his lost self-esteem and wounded dignity.

(b) The painful snakebite acts as a skilful hint. The hero is free from its appalling effects as he is unaffected by any pain (Jeffreys 1994: 82). Besides Ritsos through Neoptolemus (verses 71-72) emphasizes the hero's compromising spirit knowing that the bodily traumas do not exist, while the psychic ones may remain incurable.

(c) Philoctetes' exile appears to be dream, given that the abandoned hero approaches the objectively adverse conditions in a positive way: the violent isolation is regarded as a "courteous retreat" (verse 56), an ideal prerequisite for reflection; the intense hunger is thought to be as an ascetic challenge and as a „holiness without companionship" (verse 512); the physical hardships are treated as full control of senses.

(d) The spontaneous hatred as a result of war incidents and the consequent disappointment because of the overt frustration of his dreams is not accompanied by partly justifiable vengeful thoughts, but by unpretentious comprehension and honest leniency ${ }^{31}$.

(e) At the crucial point of the important decision, the deposed hero highlights the basic role of personal responsibility (Prokopaki 1981: 8). On this occasion, he abandons his constrained hermitage, not under the catalytic effect of a "deus ex machina", but respecting his moral obligation to the following and innocent generations as well the "unpretentious, folk" singing of ordinary people, the sailors on Neoptolemus' ship.

(f) Hercules' famous gift is replaced by "his three reputed, unique spears" 32 which do not exudes aggressive character. He has gained them with honest sweat, so they will give the fair victory.

(g) With his clear spirit Ritsos' hero fights against the passive shallowness, the unnecessary competitiveness between people and their complete indifference to

\footnotetext{
30 'In Sophocles' tragedy God's appearance is required in order to end the earthly conflict. It seems that Sophocles used to face the human things as incurably contradictory and reparable situations only with the divine intervention." (Bien 1980:127)

${ }^{31}$ Maronitis (2006: 24) points out that the political exiles have adopted the method of persistent humanisation against the destructive wrath.

${ }^{32}$ With reference to the number of Philoctetes' weapons Bien (1980: 125) mentions: "The thing, however, is not so strange when we remember that number three is the dialectic number of the triad position-opposition-composition, and therefore it is equally dear to Ritsos as was to the other dialectic writer, Nikos Kazantzakis, who needed 33,333 verses in order to recreate the 'Odyssey"'. Additionally for the relationship that connects Sophoclean Philoctetes with his bow Maronitis (2006: 19) highlights that: "Here Hercules' arch with the arrows, the traditional symbol of the archer Philoctetes, which Odysseus' intrigue is mainly intended to in the Sophoclean drama is falsely ignored. This means that the hereditary association between the archer Hercules and the archer Philoctetes is repelled. So without his Heraclean paraphernalia Philoctetes is being autonomous and the kidnapping operation in Troy changes way and meaning anymore". And Vernant, Vidal - Naquet (1988: 196) add: "The bow allows Philoctetes to survive, but makes him a cursed hunter, always at the limit of life and death, as he is on the limit of humanity and ferocity; "the wild bite of the homicide viper hurt him, but it did not kill him".
} 
moral perfection. However, he is self-inflicted in the prison of silence, which undermines the active participation and thus the qualitative upgrading of the social whole (verses 533-534).

(h) Philoctetes as a militant artist threatened by his mental capacity is invited in order to be released from his dangerous isolation (verses 507-509), to participate in the radical reformation of social goals (verses 557-558) and finally to undertake the illuminated guidance of people through the diachronic messages of poetry (verse 510).

\section{CONCLUSIONS}

The intercultural reading proves that the two writers functioning as links of the same chain, organize the mythological material and capture their personal inspiration by pointing out remarkable common parameters: (a) the dynamic presence of legendary Philoctetes that essentially defines the transition from the mythical narration to the literature reality and highlights the broad context of the semantic nuances resulting from its thorough reading; (b) the vivifying force of the ancient myth that is skilfully transformed and constructively fills the thought of modern creators.

The different access to Philoctetes by artist Gide and revolutionary Ritsos is undoubtedly an inevitable fact that is justified not only by the time gap of their works, but primarily according to their intended symbolic meanings.

The French Communist manifests the transcendent drama of a man who tries to preserve his authenticity, although he is hermetically entrapped within tyrannical alienation. In this way, he represents the flawless art that is forced to self-restraint and voluntary silence, so that not to be distorted by the degrading rules of the arbitrary power and the decadent living.

The radical poet Ritsos, with his characteristic boldness releases the hero from the ancient tradition in order to express his anti-militaristic feelings ${ }^{33}$. Through the transparent outline of Philoctetes' behaviour, he declares that only the social participation annuls the pathogenic loneliness and leads to universal happiness. His protagonist has a multi-facetted role: (a) he is the well-known mythical person with such an adventurous life; (b) he represents the bold warrior who has participated in the long-term fights of Greece for national independence and claimed for social justice and prosperity; (c) he is identical to the inspired intellectual who has triggered consciousness and overturned obsolete perceptions; (d) he symbolizes the anonymous breadwinner who is badly affected by the daily insecurities and the mighty struggle for decent survival.

\section{REFERENCES}

Albouy, P., (1969), Mythes et mythologies dans la littérature française, Colin, Paris.

Alpers, P., (2004), "The Philoctetes Problem and the Poetics of Pastoral", Representations 86, Special Issue: Music, Phythm, Language: pp. 4-19.

\footnotetext{
${ }^{33}$ About the negative reception of war conflicts Amouretti - Ruze (2001: 234) highlights: "The rejection of the war is strongly shown in the theater: the women's enslavement, the slaughter of populations, the disasters for the city. It is doubtful whether these words express a deep conviction of the futility of the war and of the moral overthrow that entails or simply the immense fatigue of the populations who have been in war for many years".
} 


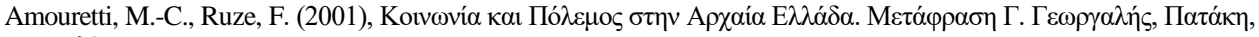
A $\theta$ ஸ́vo.

Arnim, J. de., (1893-1896), Dionis Prusaensis quem vocant Chrysostomum quae exstant omnia, Vols. I-II, Weidmann, Berlin.

Avery, H., (1965), Heracles, Philoctetes, Neoptolemus. Hermes 93, Vol. 3: pp. 279-297.

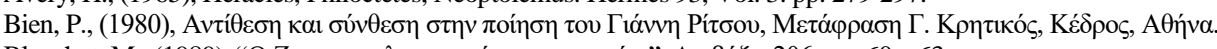

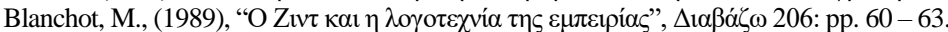

Blundell, M., (1987), "The moral character of Odysseus in Philoctetes”, Greek, Roman and Byzantine Studies 28, Vol. 3: pp. 307-329.

Burnet, J., (1903), Plato. Platonis Opera, Oxford University Press, Oxford.

Burtt, J., (1962), Lycurgus. Minor Attic Orators in two volumes, with an English translation, Harvard University Press; William Heinemann Ltd., London.

Calder, W., (1971), Sophoclean Apologia: Philoctetes. Greek, Roman and Byzantine Studies 12, Vol. 2: pp. 153-174.

Chateaubrun, J.-B., (1756), Philoctète, Academie Française, Paris.

Claude, J., (1992), André Gide et le théâtre, II volumes, Gallimard, Paris.

Craick, E., (1979), "Philoktetes: Sophoklean melodrama”, L'Antiquité Classique 48: pp. 15 - 29

Crawley, R., (1910), Thucydides. The Peloponnesian War, J. M. Dent, London; E. P. Dutton, New York.

Csürös, K., (1975), “André Gide et l'antiquité grecque”, Neohelicon 3, Vols. 1-2: pp. 343-363.

Easterling, P., (1978), "Philoctetes and Modern Criticism”, Illinois Classical Studies 3: pp. 27-39.

Eisner, R., (1987), The Road to Daulis, psychoanalysis, psychology, and classical mythology, Syracuse University Press, New York.

Feder, L., (1963), “The Symbol of the Desert Island in Sophocles' Philoctetes”, Drama Survey 3: pp.33-41.

Fenelon, F., (1762), Les aventures de Télémaque, fils d'Ulysse, Les Frères Estienne, Paris.

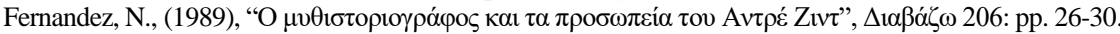

Frazer, J., (1921), Apollodorus, The Library, Vol. 2, Harvard University Press, Cambridge; William Heinemann, London

Gide, A., (1948), Journal 1889-1939, Gallimard, Paris

Griffith, M., (1990), Cabinet of the Muses: Essays on Classical and Comparative Literature in honor of Thomas G. Rosenmeyer, Scholars Press, Atlanta.

Hansaker-Hawkins, A., (1999), "Ethical tragedy and Sophocles Philoctetes", The Classical World 92, Vol. 4: pp. 337-357.

Heaney, S., (1991), The Cure at Troy. A Version of Sophocles' Philoctetes, Farrar, Strausand Giroux, New York.

Jameson, M., (1956), "Politics and the Philoctetes", Classical Philology 51, Vol. 4: pp. 217-227.

Jebb, R., $\left(1898^{2}\right)$, Sophocles: The Plays and Fragments. Part IV: The Philoctetes, Cambridge University Press, Cambridge.

Jeffreys, M., (1994), “Reading in the „Fourth Dimension”, Modern Greek Studies 2: pp. 61-101.

Jones, W., (1918), Pausanias. Pausanias Description of Greece with an English translation in 4 Volumes, Harvard University Press, Cambridge; William Heinemann, London.

Korsmeyer, C., (2011), Savoring Disgust: The Foul and the Fair in Aesthetics, Oxford University Press, Oxford.

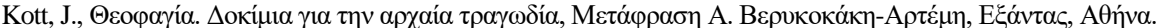

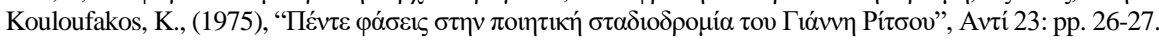

Lada-Richards, I., (1997), "Neoptolemus and the Bow: Ritual thea and Theatrical Vision in Sophocles' Philoctetes", The Journal of Hellenic Studies 117: pp. 179-183.

Lerner, L., (1980). The Man I Killed, Secker and Warburg, London.

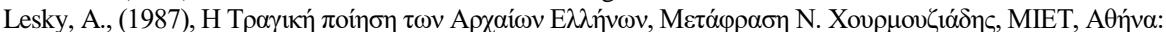

Levi-Strauss, C., (1974), Anthropologie structurale, Volume I, Plon, Paris.

Louria, Y., (1952), "Le contenu latent du Philoctète giden", French Review 25: pp. 348-54.

Mandel, O., (1981), Philoctetes and the Fall of Troy. Plays, Documents, Iconography, Interpretations Including Versions by Sophocles, André Gide, Oscar Mandel and Heiner Müller, Nebraska University Press, London.

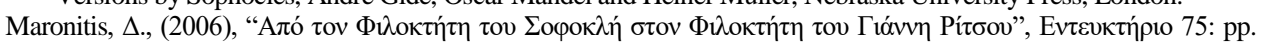
16-24.

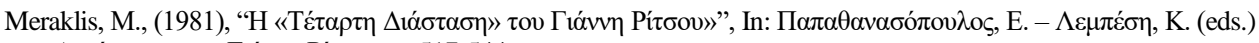

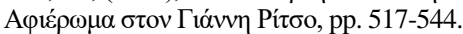

Murray, A., (1919), Homer. The Odyssey with an English Translation, Vols. 1-2, Harvard University Press, Cambridge; William Heinemann, London.

Murray, A., (1924), Homer. The Iliad with an English Translation, Vols. 1-2, Harvard University Press, Cambridge; William Heinemann, London.

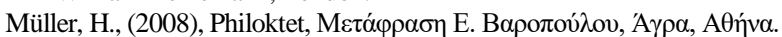

O’ Brien, J., (1953), Portrait of André Gide. A Critical Biography, Seckek \& Warburg, London.

Ondaatje, M., (1979). "There's a trick with a knife I'm learning to do", W.W. Norton, New York. 
Pearson, A., (1917), The Fragments of Sophocles, Vol. 2., Cambridge University Press, Cambridge.

Podlecki, A., (1966), “The power of the word in Sophocles' Philoctetes", Greek, Roman and Byzantine Studies 7: pp. 233-250.

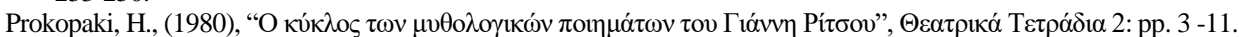

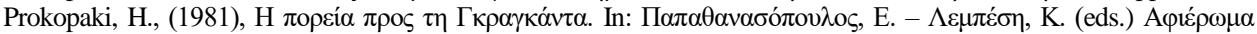

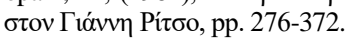

Pucci, P. (1994), “Gods' Intervention and Epiphany in Sophocles”, The American Journal of Philology 115, Vol. 1: pp. 15-46.

Rich, A., (1976), Twenty-one love poems, Effies Press, Emeryville.

Roisman, H., (2005), Sophocles: Philoctetes, Gerald Duckworth \& Co., London.

Rose, H., (1933), Hyginus. Hygini Fabulae, A. W. Sythoff, Leiden.

Sandys, J., (1937), Pindar. The Odes of Pindar including the Principal Fragments with an Introduction and an English Translation, Harvard University Press, Cambridge; William Heinemann, London.

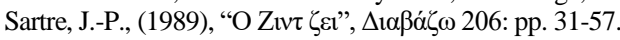

Stroh, W., (1981), "Tröstende Musen: zur literarhistorischen Stellung und Bedeutung von Ovids Exilgedichten”, In: Temporini, H.- Haase, W. (Hrsg) Aufstieg und Niedergang der römischen welt II, 31, Vol. 4: pp. 2638-2684.

Taplin, O., $\left(2003^{2}\right)$, Greek Tragedy in Action, Routledge, Oxon.

Tessitore, A., (2003), "Justice, politics and piety in Sophocles' Philoctetes", The Review of Politics 65, Vol. 1: pp. 61-88.

Todorov, T., (1981), Mikhail Bakhtine, Le Principle dialogique, Seuil, Paris.

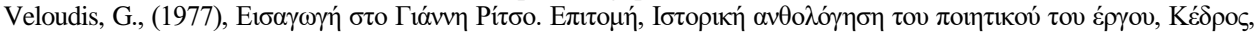
A $\theta \dot{v} v \alpha$.

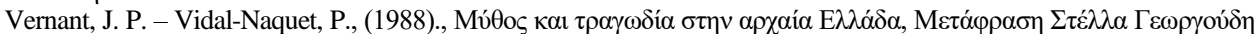

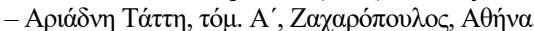

Watson-Williams, H., (1967), André Gide and the Greek Myth. A Critical Study, Clarendon Press, Oxford.

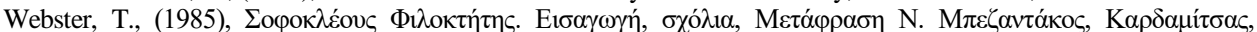
A $\theta \dot{v} v \alpha$.

Westphal, R., (1866), Scriptores metrici graeci. Vol. 1: Hephaestionis De metris enchiridion et De poemate libellus, cum scholiis et Trichae Epitomis, adjecta Procli Chrestomathis grammatica, Teubner, Leipzig.

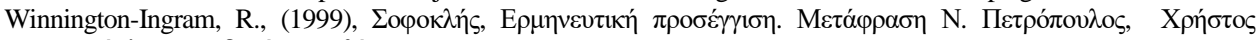

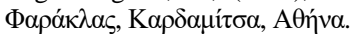

Wordsworth, W., (1888), The Complete Poetical Works, MacMillan, London.

\section{INTERTEKSTUALNI PARAMETRI DRAMSKE LIČNOSTI SOFOKLOVOG FILOKTETA KOD ANDREA ŽIDA I JANISA RITSOSA}

Nesumnjivo je to da konstruktivan, dijalektički odnos među književnim delima odražava značajnu dijahronijsku potrebu čoveka da se iznova okrene ćelijama arhetipske srži, ali i osavremenjenim motivima koji poreklo vode od njihove mitološke osnove. Ova univerzalna činjenica potvrđuje se i time što poznati i nadareni umetnici crpu iz nemerljive duhovnosti i dubokih pouka koje se spontano rađaju u pojedinim stihovima klasičnih grčkih tragedija. U savršenoj harmoniji sa intelektualno prosvećenim Sofoklom, Andre Žid, pronicljivi Protej francuske dramaturgije, i Janis Ritsos, revolucionar savremene grčke poezije, bave se Filoktetom, legendarnim strelcem; tako se puritanska žica buržoaske arogancije $i$ razuzdana, mladalačka impulsivnost premošćuju u Židovom „Filoktetu” (1898). U isto vreme se antikonvencionalni, hedonistički nastrojeni pesnik savršeno usklađuje sa standardima tradicionalne književnosti. Slično, u pesmi pod istim nazivom iz nagrađivane zbirke „Četvrta dimenzija” (1963-1965), nemarksistička inspiracija Janisa Ritsosa oslobođenog političkih stavova približila se egzistencijalnoj ravnoteži svesnog izbora između aktivne društvene odgovornosti i potčinjene umetnosti.

Ključne reči: Filoktet, Sofokle, Žid, Ritsos 